\title{
Water quality analysis of River Yamuna using water quality index in the national capital territory, India (2000-2009)
}

\author{
Deepshikha Sharma · Arun Kansal
}

Received: 20 May 2011 / Accepted: 28 July 2011 / Published online: 12 August 2011

(c) The Author(s) 2011. This article is published with open access at Springerlink.com

\begin{abstract}
River Yamuna, in the national capital territory (NCT), commonly called Delhi (India), has been subjected to immense degradation and pollution due to the huge amount of domestic wastewater entering the river. Despite the persistent efforts in the form of the Yamuna Action Plan phase I and II (YAP) (since 1993 to date), the river quality in NCT has not improved. The restoration of river water quality has been a major challenge to the environmental managers. In the present paper, water quality index (WQI) was estimated for the River Yamuna within the NCT to study the aftereffects of the projects implemented during YAP I and II. The study was directed toward the use of WQI to describe the level of pollution in the river for a period of 10 years (2000-2009). The study also identifies the critical pollutants affecting the river water quality during its course through the city. The indices have been computed for pre-monsoon, monsoon and post-monsoon season at four locations, namely Palla, ODRB, Nizamuddin and Okhla in the river. It was found that the water quality ranged from good to marginal category at Palla and fell under poor category at all other locations. BOD, DO, total and fecal coliforms and free ammonia were found to be critical parameters for the stretch.
\end{abstract}

Keywords CCME WQI 1.0 - Water quality index . River Yamuna $\cdot$ DO $\cdot$ BOD $\cdot$ Coliform

D. Sharma $(\bowtie)$

Department of Natural Resources, TERI University, 10-Institutional Area, Vasant Kunj, Delhi 110070, India e-mail: deepshikha.k.sharma@gmail.com

\section{A. Kansal}

Department of Natural Resources, TERI University, 10-Institutional Area, Vasant Kunj, Delhi 110070, India e-mail: akansal@teri.res.in

\section{Introduction}

At the present time, to safeguard freshwater resources, it is important to develop a comprehensive river water quality monitoring program all over the world. A river quality monitoring program (RQMP) could be designed on the basis of the information on the existing water quality, standards, anthropological effects and the 'use' criteria. The monitored data help the planners both at the national and international levels to develop various environmental programs. However, when a large number of samples and parameters are monitored, it becomes difficult to evaluate and present the water quality as a single unit (Chapman 1992; Pesce and Wunderlin 2000). Traditionally, river water quality has been assessed by comparing the values with the local norms. However, this technique does not provide any information on the spatial and temporal trends of the overall quality (Debels et al. 2005). Thus, modern techniques such as water quality indices (WQI) and water quality modeling were developed. The advanced modeling techniques require time and extensive calibration and validation, as well as knowledge about hydraulics and other domains. Thus, applying water quality modeling for an immediate solution is not a feasible option. The models should be used mainly for assessment and management purposes (Chapman 1992; Rauch et al. 1998; Shanahan et al.1998; Somlyody et al. 1998). According to StambukGiljanovic (1999), WQI is a mathematical tool which has the ability to provide a single number for the large quantities of water quality data in a comprehensive manner. Therefore, it is a simple tool for decision makers on the quality and possible uses of a given water body (Bordalo et al. 2001; Cude 2001; Kannel et al. 2007).

In the present study, the Canadian Council of Ministers of the Environment-Water Quality Index 1.0 (CCME WQI) 
was used, which is a well-accepted and universally applicable computer model for evaluating the water quality index (Canadian Council of Ministers of the Environment (CCME) 2001; Cash et al. 2001; Husain 2001; Lumb et al. 2002, 2006; Sharma 2002; Khan et al. 2003; Paterson et al. 2003). It can combine a variety of different measurement units in a single metric and is effective as a communication tool. The index has the ability to convey relative differences in water quality between sites even when the same objectives and variables are used (Canadian Council of Ministers of the Environment (CCME) 2001).

The main aim of the study was to evaluate the impacts of YAP I and II. The study highlights the assorted vital parameters affecting the river water quality at the various locations in the capital city of India The study is divided into three phases: (i) application of CCME WQI 1.0. to the river stretch between Palla and Okhla to evaluate water quality index of six selected parameters on the river stretch; (ii) establishing the correlation between the water quality index and the different parameters at locations; (iii) to identify the most critical parameters affecting the water quality of the river.

\section{Water quality index}

Categorization of water quality started in the mid-twentieth century by Horton (1965) and Landwehr (1974). Brown et al. (1970) developed a general WQI. More than 20 water quality indices being used till late 1970s were reviewed by Ott (1978) and Steinhart et al. (1981). Steinhart et al. (1982) applied a novel environmental quality index to sum up technical information on the status and trends in Great Lakes ecosystem. Water Quality Guidelines Task Group of the CCME introduced WQI in Canada, in the mid-1990s (Dunn 1995; H'ebert 1996; Rocchini and Swain 1995). Said et al. (2004) studied some frequently used WQI in public domains such as the US National Sanitation Foundation Water Quality Index, NSFWQI (Brown et al. 1970), Florida Stream Water Quality Index, FWQI (SAFE 1995), British Columbia Water Quality Index, BCWQI (Zandbergen and Hall 1998), Oregon Water Quality Index, OWQI (Cude 2001) and the Canadian Water Quality Index (Canadian Council of Ministers of the Environment (CCME) 2001). The original BCWQI was modified into the CCME WQI, which was certified by the Canadian Council of Ministers of the Environment (CCME) 2001.

In India, the pioneer work on WQI was done by Bhargava (1983a, b, c), wherein the water quality is expressed as a number (ranging from 0 for highly/extremely polluted to 100 for absolutely unpolluted water) representing the integrated effect of the parameters amplifying the pollution load. The Bhargava's WQI includes the effect of weight of each variable (pollution parameter) in the sensitivity function values of the various pollution variables relevant to a particular use.

WQI can be evaluated on the basis of various physical, chemical and bacteriological parameters. In the developing countries, the biggest challenge has been to develop costeffective pollution control strategies with analytical cost as a limiting factor due to restricted funds (Ongley 1998; Ongley and Booty 1999). Therefore, for such situations only few critical parameters must be used to evaluate WQI (Kannel et al. 2007). Water quality of many Indian rivers has been comprehensively studied, analyzed and reported according to their suitability for various beneficial uses (Bhargava 1983c, 1994; CPCB 2000, 2002; HT 2004; Upadhyay et al. 2010). Pesce and Wunderlin (2000) used WQI to assess the water quality of the Suquia River (Argentina). Bordalo et al. (2001) compared the indices and the variations among them. The water quality in different reservoirs, bays and rivers was evaluated using dissolved oxygen (DO) and the parameters affecting DO. Rudolf et al. (2002) estimated the effect of industrial and municipal effluents on the waters of San Vicente Bay (Chile) by using DO content as an index of water quality. DO deficit was used as the environmental indicator to assess the WQI in the watersheds of Las Rozas, Madrid (Spain) by Sanchez et al. (2006). Kannel et al. (2007) applied WQI to evaluate spatial and temporal changes of the water quality in the Bagmati River Basin (Nepal).

\section{Description of the study area}

The main stream of the River Yamuna originates from the Yamunotri glacier near Bandar Punch $\left(38^{\circ} 59^{\prime} \mathrm{N} 78^{\circ} 27^{\prime} \mathrm{E}\right)$ in the Mussourie range of the lower Himalayas at an elevation of about $6,387 \mathrm{~m}$ above mean sea level $(\mathrm{msl})$ in the District Uttarkashi (Uttranchal). The catchment (Table 1) of the river system covers parts of the states of Uttaranchal, Uttar Pradesh, Himachal Pradesh, Haryana, Rajasthan, Madhya Pradesh and the entire state of NCT (CPCB 2001-02(a)).

Table 1 Catchment of River Yamuna

\begin{tabular}{lcc}
\hline Name of state & $\begin{array}{l}\text { Total catchment } \\
\text { area in Yamuna } \\
\text { (in Sq. Km.) }\end{array}$ & \% contribution \\
\hline U.P. (including Uttaranchal) & 74,208 & 21.5 \\
Himachal Pradesh & 5,799 & 1.6 \\
Haryana & 21,265 & 6.5 \\
Rajasthan & 102,883 & 29.8 \\
Madhya Pradesh & 14,028 & 40.6 \\
Delhi & 1,485 & 0.4 \\
\hline
\end{tabular}

Source: CPCB (2006-07) 
The total length of the Yamuna in NCT's municipal boundary is approximately $50 \mathrm{~km}$. The river enters the city $1.5 \mathrm{~km}$ above Village Palla and leaves at Jaitpur, downstream $(\mathrm{d} / \mathrm{s})$ of the Okhla Bridge (Fig. 1). The study covers the complete NCT's stretch. The wastewater streams via treatment plants that enter the river at different points along the stretch are as follows: Najafgarh, Magazine Road, Sweepers Colony, Khyber Pass, Metcalf, Mori Gate, Tonga Stand, Civil Mill, Power House, Moat, Sen Nursing Home, No. 12 A, No. 14, Barapulla, Maharani Bagh, Kalkaji, Tuglakabad, Shahdara, Sarita Vihar, Near LPG Plant, Near Bridge Sarita Vihar and Tehkhand drains. The river also gets direct load from the wastewater treatment plant located at Okhla and from a diversion called Hindon Cut. Water for drinking purposes is supplied to NCT and Agra from the two points: Wazirabad Waterworks and Agra Canal, respectively (Table 2). River Yamuna is the primary source of drinking water for the city with a population of over 13 million. Over the past few decades, rapid deterioration in the river water quality has been observed.

In 1993 and 2004, YAP I and II were launched, respectively by the Ministry of Environment and Forests (MoEF), Government of India (GoI) in order to rejuvenate the river, with key focus on the NCT stretch. The total funds released for both YAP I and II are estimated to be Rs. 700 and Rs. 624 crore, respectively (River Action Plan, http://envfor.nic.in/nrcd/NRCD/YAP.htm). Central Pollution Control Board (CPCB), Central Water Commission (CWC) and Delhi Pollution Control Committee (DPCC) measure and monitor the water quality of the River Yamuna in NCT. In order to achieve the ZERO sewage, the GoI focused on laying of interceptors to trap major drains and also the rehabilitation of exiting sewerage networks. In this context, WQIs can be used to summarize the large amounts of water quality datasets into simple terms for reporting to environmental planners and public in a reliable manner. The potential threat to various uses of water such as habitat for aquatic life, irrigation water for agriculture and livestock, recreation and esthetics, and drinking water supplies can very well be predicted by the overall quality of water bodies.

The present study illustrates the application of the CCME WQI 1.0. to observe the changes in water quality in the Yamuna River, India, at the following four sites (Fig. 1):

1. Palla

2. Old daily railway bridge (ODRB)

3. Nizamuddin (midstream)

4. Okhla (Agra Canal)

Palla is $23 \mathrm{~km}$ upstream (u/s) Wazirabad barrage near the flood control office. Thereafter, three other locations were chosen, namely ODRB (22 km d/s Palla), Nizamuddin (29 km d/s Palla) and Okhla (meeting Agra Canal) (39 km d/s Palla), to assess the spatial and temporal distribution of water quality.

\section{Conceptual framework of CCME Water Quality Index}

The CCME WQI comprises three factors and is well documented (Canadian Council of Ministers of the Environment

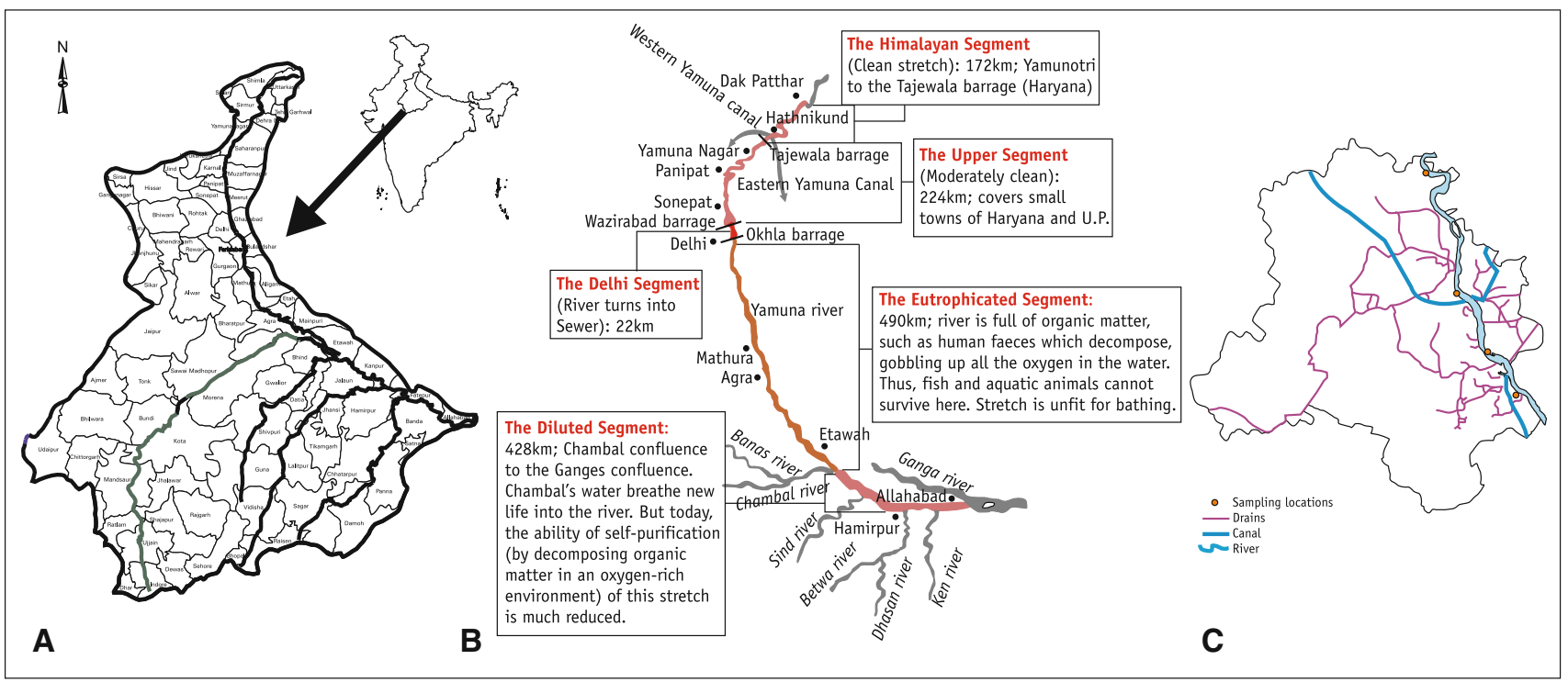

Fig. 1 Description of the study area. a Basin map of River Yamuna. b River classification according to pollution. $\mathbf{c}$ Location of monitoring stations (CPCB) in NCT (Delhi), India. Figure has been adapted from CPCB (2006-07) and modified

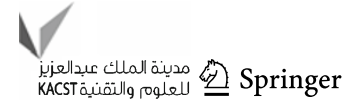


Table 2 Wastewater drain characteristics
Negative sign signifies withdrawal

Source: CPCB (2000); CPCB (1999-2000)

${ }^{a}$ NEERI (1996)

Source: Paliwal et al. (2007)

\begin{tabular}{|c|c|c|c|c|c|}
\hline S. no. & Discharge/withdrawal & Flow $\left(\mathrm{m}^{2} / \mathrm{s}\right)$ & DO $(\mathrm{mg} / \mathrm{l})$ & BOD (mg/l) & Load (tons/day) \\
\hline 1 & Head water & 15.0 & 8.10 & 6.00 & - \\
\hline 2 & Wazirabad waterworks ${ }^{\mathrm{a}}$ & -11.1 & - & - & - \\
\hline 3 & Najafgarh drain & 26.5 & 0.0 & 75.00 & 171.720 \\
\hline 4 & Magazine Road drain & 0.04 & 0.0 & 308.18 & 1.19682 \\
\hline 5 & Sweeper Colony drain & 0.04 & 0.0 & 139.25 & 0.4813 \\
\hline 6 & Khyber Pass drain & 0.04 & 0.0 & 42.60 & 0.1546 \\
\hline 7 & Metcalf House drain & 0.08 & 0.0 & 112.83 & 0.7506 \\
\hline 8 & Qudusia + Mori Gate drain & 0.20 & 0.0 & 156.30 & 2.7144 \\
\hline 9 & Tonga Stand drain & 0.05 & 0.0 & 184.30 & 0.7962 \\
\hline 10 & Civil Military drain & 0.5 & 0.0 & 114.00 & 4.8923 \\
\hline 11 & Power House drain & 0.41 & 0.0 & 163.00 & 5.7276 \\
\hline 12 & Sen Nursing Home drain & 0.31 & 0.0 & 168.33 & 4.4606 \\
\hline 13 & Drain no. 14 & 0.83 & 0.0 & 133.35 & 9.5282 \\
\hline 14 & Barapulla drain & 1.23 & 0.0 & 63.00 & 6.6951 \\
\hline 15 & Hindon $\mathrm{Cut}^{\mathrm{a}}$ & 14.48 & 0.1 & 45.00 & 56.2944 \\
\hline 16 & Maharni Bagh drain & 0.39 & 0.0 & 258.85 & 8.8117 \\
\hline 17 & Agra Canal $^{\mathrm{a}}$ & -45.83 & 1.2 & 20.00 & - \\
\hline \multirow[t]{2}{*}{18} & Okhla Barrage $^{a}$ & 3.62 & 0.0 & 70.00 & 21.8938 \\
\hline & Total & & & & 296.119 \\
\hline
\end{tabular}

(CCME) 2001). It is based on a formula developed by the British Columbia Ministry of Environment, Lands and Parks and modified by the Alberta Environment. The index is based on a combination of three factors:

1. Scope: the number of variables whose objectives are not met.

2. Frequency: the frequency with which the objectives are not met.

3. Amplitude: the amount by which the objectives are not met.

All these three factors are combined to produce a single value (between 0 and 100) that describes water quality. These numbers are divided into five descriptive categories to simplify presentation. It can be applied to different environmental settings since the specific variables, objectives and time period used in the index are not specified and, indeed, could vary from region to region, depending on local conditions and issues. Minimum of four variables must be sampled at least four times to be used in the calculation of index values. The calculation is done in the following steps:

$F_{1}$ (scope) represents the percentage of variables that do not meet their objectives at least once during the time period under consideration (failed variables), relative to the total number of variables measured:

$F_{1}=\left(\frac{\text { Number of failed variables }}{\text { Total number of variables }}\right) \times 100$
$F_{2}$ (frequency) represents the percentage of individual tests that do not meet the objectives (failed tests):

$F_{2}=\left(\frac{\text { Number of failed tests }}{\text { Total number of tests }}\right) \times 100$

$F_{3}$ (amplitude) represents the amount by which failed test values do not meet their objectives. $F_{3}$ is calculated in three steps.

(i) The number of times by which an individual concentration is greater than (or less than, when the objective is a minimum) the objective is termed an "excursion" and is expressed as follows. When the test value must not exceed the objective:

Excursion $_{i}=\left(\frac{\text { failed test value }_{i}}{\text { objective }_{j}}\right)-1$

For the cases in which the test value must not fall below the objective:

Excursion $_{i}=\left(\frac{\text { objective }_{j}}{\text { failed test value }_{i}}\right)-1$

(ii) The amount by which individual tests are out of compliance is calculated by summing the excursions of individual tests from their objectives and dividing by the total number of tests (both those meeting objectives and those not meeting objectives). This variable, referred to as the normalized sum of excursions, or nse, is calculated as: 
$n s e=\left(\frac{\sum_{i=1}^{n} \text { excursion }_{i}}{\text { No. of tests }}\right)$

(iii) $F_{3}$ is then calculated by an asymptotic function that scales the normalized sum of the excursions from objectives (nse) to yield a range between 0 and 100.

$F_{3}=\left(\frac{n s e}{0.01 n s e+0.01}\right)$

Once the factors have been obtained, the index itself can be calculated by summing the three factors as if they were vectors. The sum of the squares of each factor is therefore equal to the square of the index. This approach treats the index as a three-dimensional space defined by each factor along one axis. With this model, the index changes in direct proportion to changes in all three factors.

CCME Water Quality Index:

$\mathrm{CCMEWQI}=100-\left(\frac{\sqrt{F_{1}^{2}+F_{2}^{2}+F_{3}^{2}}}{1.732}\right)$

The divisor 1.732 normalizes the resultant values to a range between 0 and 100, where 0 represents the "worst" water quality and 100 represents the "best" water quality. Once the CCME WQI value has been determined, water quality is ranked by relating it to one of the following categories:

Excellent (CCME WQI Value 95-100)—water quality is protected with a virtual absence of threat or impairment; conditions are very close to natural or pristine levels
Good

(CCME WQI Value 80-94)-water quality is protected with only a minor degree of threat or impairment; conditions rarely depart from natural or desirable levels

Fair (CCME WQI Value 65-79) - water quality is usually protected, but occasionally threatened or impaired; conditions sometimes depart from natural or desirable levels

Marginal (CCME WQI Value 45-64) - water quality is frequently threatened or impaired; conditions often depart from natural or desirable levels

Poor (CCME WQI Value 0-44)-water quality is almost always threatened or impaired; conditions usually depart from natural or desirable levels (Canadian Council of Ministers of the Environment (CCME) 2001)

The WQI software has been prepared in Visual Basic by CCME, which can be implemented in MS Excel for computational purpose. Instructions for the implementation are well described in the Calculator Version 1.0 (Canadian Council of Ministers of the Environment (CCME) 2001). The output is available in the form of a table displaying the values of $F_{1}, F_{2}, F_{3}$, WQI, number of samples, number of variables tested, total number of variables, total tests, failed tests, passed tests and tests below detection level. A frequency histogram of $F_{1}, F_{2}$ and $F_{3}$ is also given (Lumb et al. 2006).

\section{Application of CCME WQI}

The critical parameters chosen to evaluate the WQI were $\mathrm{pH}, \mathrm{DO}, \mathrm{BOD}$, total coliforms (TC), fecal coliforms (FC) and free ammonia. The parameters are used to classify the Indian rivers according to the usage (Table 3). $\mathrm{pH}$ is important to quantify the health of a river since the water is used by public for direct consumption such as drinking,
Table 3 CPCB water quality standards for River Yamuna, Delhi

(http://www.cpcb.nic.in, Accessed on 11th January 2011)

\begin{tabular}{|c|c|c|c|}
\hline $\begin{array}{l}\text { Category of water } \\
\text { Best usage }\end{array}$ & $\begin{array}{l}\text { A } \\
\text { Drinking water source } \\
\text { without conventional } \\
\text { treatment, but after } \\
\text { disinfection }\end{array}$ & $\begin{array}{l}\text { B } \\
\text { Outdoor bathing } \\
\text { (organized) }\end{array}$ & $\begin{array}{l}\text { C } \\
\text { Public water supply with } \\
\text { approved treatment equal to } \\
\text { coagulation, sedimentation } \\
\text { and disinfection. }\end{array}$ \\
\hline $\mathrm{pH}$ & $6.5-8.5$ & $6.5-8.5$ & $6.0-9.0$ \\
\hline Dissolved oxygen (mg/l) & Not less than 6.0 & Not less than 5.0 & Not less than 4.0 \\
\hline $\begin{array}{l}\text { Biochemical oxygen } \\
\text { demand }(\mathrm{mg} / \mathrm{l})\end{array}$ & Not more than 2.0 & Not more than 3.0 & Not more than 3.0 \\
\hline $\begin{array}{l}\text { Total coliform } \\
\text { (MPN/100 ml) }\end{array}$ & 50 or less & 500 or less & 5,000 or less \\
\hline $\begin{array}{l}\text { Fecal coliform } \\
\text { (MPN/100 ml) }\end{array}$ & 20 or less & 200 or less & 2,000 or less \\
\hline Free ammonia $(\mathrm{mg} / \mathrm{l})$ & Not more than 1.2 & Not more than 1.2 & Not more than 1.5 \\
\hline
\end{tabular}


bathing, etc. DO is a very important indicator of a water body's ability to support aquatic life. Factors affecting DO are temperature, volume and velocity of water flowing in the river, organic wastes, climate/season, type and number of organisms in the water body, altitude, dissolved or suspended solids and amount of nutrients in the water. Rivers with lower oxygen levels often smell bad because of waste products produced by organisms surviving in low oxygen environments. In addition, low DO concentrations also mobilize the trace metals (Murphy 2007).

High BOD indicates that the levels of DO are falling, with potentially dangerous implications for the river's biodiversity. Elevated BOD demand can be caused by high levels of organic pollution (caused usually by poorly treated wastewater) and high nitrate levels facilitating high plant growth. The degree to which TC and FC are present in water indicates the water quality. It negatively impacts on the DO of the river. Free ammonia (unionized ammonia, $\mathrm{NH}_{3}$ ) depletes $\mathrm{DO}$ in water via oxidation.

The WQI was measured annually as well as seasonally (pre-monsoon, monsoon and post-monsoon periods) for all the four sites and for a period of 10 years. The CPCB objectives for class $\mathrm{C}$ (drinking water source after conventional treatment and disinfection) were applied to all the sites. The WQI was determined by combining variables of interest for a particular use or application, named herein as protocols (Table 3).The index was calculated using river quality data monitored by CPCB (CPCB 2006-07) and

Table 4 Location-wise statistics of water quality parameters

\begin{tabular}{|c|c|c|c|c|c|}
\hline & BOD & Total coliforms & Free ammonia & Dissolved oxygen & $\mathrm{pH}$ \\
\hline \multicolumn{6}{|l|}{ Palla } \\
\hline Mean & 1.58 & $27,445.06$ & 0.48 & 8.13 & 7.90 \\
\hline Standard error & 0.08 & $2,893.64$ & 0.06 & 0.17 & 0.04 \\
\hline Median & 1.00 & $15,000.00$ & 0.21 & 7.80 & 7.99 \\
\hline Mode & 1.00 & $3,300.00$ & 0.16 & 7.60 & 8.02 \\
\hline Standard deviation & 0.89 & $31,565.90$ & 0.61 & 1.89 & 0.48 \\
\hline Minimum & 1.00 & 150.00 & 0.01 & 5.00 & 6.81 \\
\hline Maximum & 6.00 & $201,000.00$ & 3.55 & 14.30 & 8.92 \\
\hline \multicolumn{6}{|l|}{ ODRB } \\
\hline Mean & 23.35 & $9,461,853.10$ & 11.27 & 0.92 & 7.48 \\
\hline Standard error & 1.11 & $1,779,056.56$ & 0.77 & 0.14 & 0.03 \\
\hline Median & 24.00 & $1,005,604.50$ & 10.69 & 0.30 & 7.45 \\
\hline Mode & 14.00 & 2015605.00 & 8.98 & 0.01 & 7.39 \\
\hline Standard deviation & 11.67 & $18,827,764.89$ & 8.03 & 1.35 & 0.34 \\
\hline Minimum & 6.00 & $5,606.00$ & 0.30 & 0.01 & 6.80 \\
\hline Maximum & 56.00 & $90,015,605.00$ & 30.68 & 5.60 & 8.53 \\
\hline \multicolumn{6}{|l|}{ Nizamuddin } \\
\hline Mean & 18.84 & $20,955,448.17$ & 11.49 & 1.02 & 7.49 \\
\hline Standard Error & 1.06 & $8,469,334.60$ & 0.78 & 0.12 & 0.03 \\
\hline Median & 19.00 & $1,885,000.00$ & 11.01 & 0.50 & 7.46 \\
\hline Mode & 5.00 & $275,000.00$ & 9.30 & 0.01 & 7.40 \\
\hline Standard deviation & 11.11 & $88,827,130.62$ & 8.17 & 1.17 & 0.34 \\
\hline Minimum & 3.00 & $69,000.00$ & 0.01 & 0.01 & 6.81 \\
\hline Maximum & 51.00 & $890,000,000.00$ & 31.00 & 4.60 & 8.54 \\
\hline \multicolumn{6}{|l|}{ Okhla } \\
\hline Mean & 13.68 & $7,046,199.14$ & 8.96 & 1.43 & 7.53 \\
\hline Standard error & 0.90 & $1,646,901.82$ & 0.58 & 0.15 & 0.03 \\
\hline Median & 11.00 & $750,000.00$ & 7.59 & 1.00 & 7.50 \\
\hline Mode & 5.00 & $11,000.00$ & 1.64 & 0.10 & 7.45 \\
\hline Standard deviation & 9.74 & $17,889,932.97$ & 6.28 & 1.45 & 0.35 \\
\hline Minimum & 2.00 & $99,000.00$ & 0.06 & 0.01 & 6.87 \\
\hline Maximum & 58.00 & $142,000,000.00$ & 27.47 & 5.80 & 8.82 \\
\hline
\end{tabular}

Statistical summary of data obtained from CPCB and CWC 
CWC. The statistical summary of water quality data for all locations is given in Table 4.

\section{Results}

The annual WQI for all the locations is presented in Fig. 2. The WQI for pre-, monsoon and post-monsoon seasons are shown in Table 5. The histograms for three factors have been shown in Figs. 3, 4 and 5 representing the scope, frequency and amplitude. The maximum number of variables whose objectives are not met lie in the range from 85 to 90 . The frequency with which the objectives are not met is highest between the range 65 and 70 and the amount by which the objectives are not met is highest between 95 and 100.

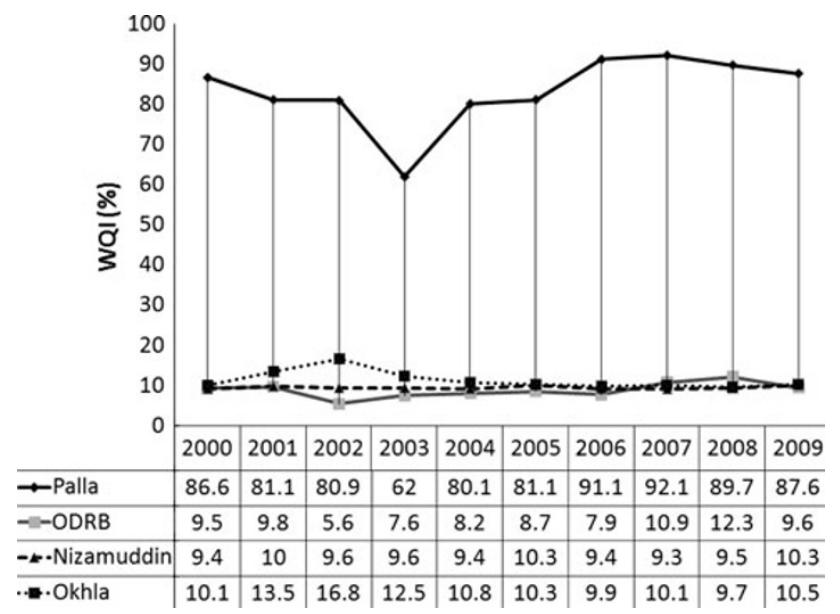

WQI at Palla, NCT

It was observed (Fig. 2) that the range of CCME WQI for River Yamuna at Palla falls under good category except for 2003, where it is under marginal category mainly due to addition of wastewater containing higher levels of TC and FC. The amplitude calculated by the index helps in identifying the critical parameters after quantifying the amount by which failed test values do not meet the objectives. At Palla, only TC and FC were found to be critical and other parameters were well within the limits. Seasonal WQI also reflects marginal category in the pre-monsoon season and good category in both the monsoon and post-monsoon season (Table 5). The water quality at this location reflects the impact of domestic and industrial discharges from the Sonipat District (Haryana) u/s Palla.

\section{WQI at ODRB, Nizamuddin and Okhla, NCT}

The water quality falls under poor category for the entire study period (Fig. 2). It was found that water quality was always threatened annually and rarely met the desirable value. The pre-monsoon season is worst affected with WQI falling largely into poor category throughout the study period with slight improvement seen in both monsoon and post-monsoon seasons. However, since 2002, WQI fell into the poor category (Table 5). Water quality parameters including BOD, DO, TC, FC and free ammonia do not meet the water quality criteria except the $\mathrm{pH}$ value. The water quality at these locations is primarily impacted by wastewater discharge generated from the NCT, entering the River Yamuna through various drains.

Fig. 2 WQI (2000-2009)

Table 5 Seasonal CCME WQI

\begin{tabular}{|c|c|c|c|c|c|c|c|c|c|c|c|c|}
\hline \multirow[b]{2}{*}{ Year } & \multicolumn{3}{|l|}{ Palla } & \multicolumn{3}{|l|}{ ODRB } & \multicolumn{3}{|c|}{ Nizamuddin } & \multicolumn{3}{|l|}{ Okhla } \\
\hline & $\begin{array}{l}\text { Pre- } \\
\text { Monsoon }\end{array}$ & Monsoon & $\begin{array}{l}\text { Post- } \\
\text { Monsoon }\end{array}$ & $\begin{array}{l}\text { Pre- } \\
\text { Monsoon }\end{array}$ & Monsoon & $\begin{array}{l}\text { Post- } \\
\text { Monsoon }\end{array}$ & $\begin{array}{l}\text { Pre- } \\
\text { Monsoon }\end{array}$ & Monsoon & $\begin{array}{l}\text { Post- } \\
\text { Monsoon }\end{array}$ & $\begin{array}{l}\text { Pre- } \\
\text { Monsoon }\end{array}$ & Monsoon & $\begin{array}{l}\text { Post- } \\
\text { Monsoon }\end{array}$ \\
\hline 2000 & Marginal & Good & Good & Poor & Marginal & Marginal & Poor & Marginal & Marginal & Poor & Marginal & Marginal \\
\hline 2001 & Marginal & Good & Good & Poor & Marginal & Marginal & Poor & Marginal & Marginal & Poor & Marginal & Marginal \\
\hline 2002 & Marginal & Good & Good & Poor & Poor & Poor & Poor & Poor & Poor & Poor & Poor & Poor \\
\hline 2003 & Marginal & Good & Good & Poor & Poor & Poor & Poor & Poor & Poor & Poor & Poor & Poor \\
\hline 2004 & Marginal & Good & Good & Poor & Poor & Poor & Poor & Poor & Poor & Poor & Poor & Poor \\
\hline 2005 & Marginal & Good & Good & Poor & Poor & Poor & Poor & Poor & Poor & Poor & Poor & Poor \\
\hline 2006 & Marginal & Good & Good & Poor & Poor & Poor & Poor & Poor & Poor & Poor & Poor & Poor \\
\hline 2007 & Marginal & Good & Good & Poor & Poor & Poor & Poor & Poor & Poor & Poor & Poor & Poor \\
\hline 2008 & Marginal & Good & Good & Poor & Poor & Poor & Poor & Poor & Poor & Poor & Poor & Poor \\
\hline 2009 & Marginal & Good & Good & - & Poor & Poor & Poor & Poor & Poor & Poor & Poor & Poor \\
\hline
\end{tabular}




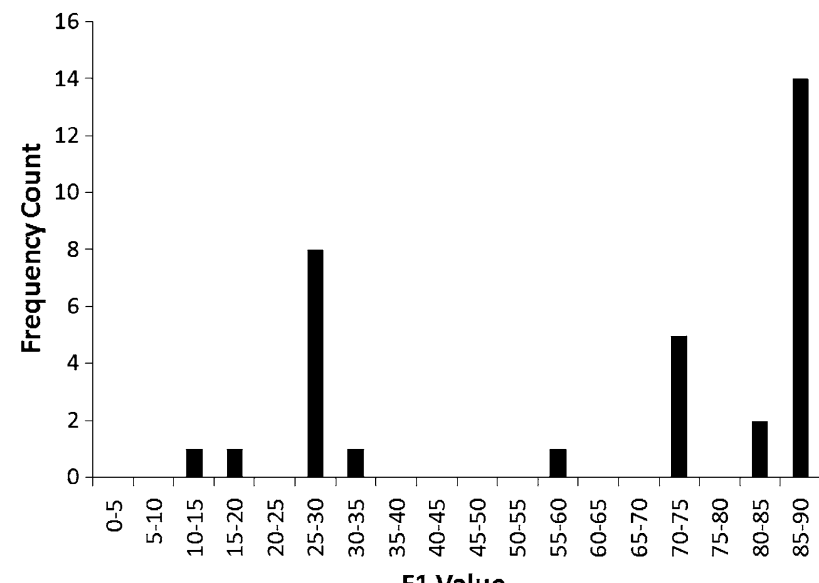

Fig. 3 Histogram showing distribution of F1 parameter

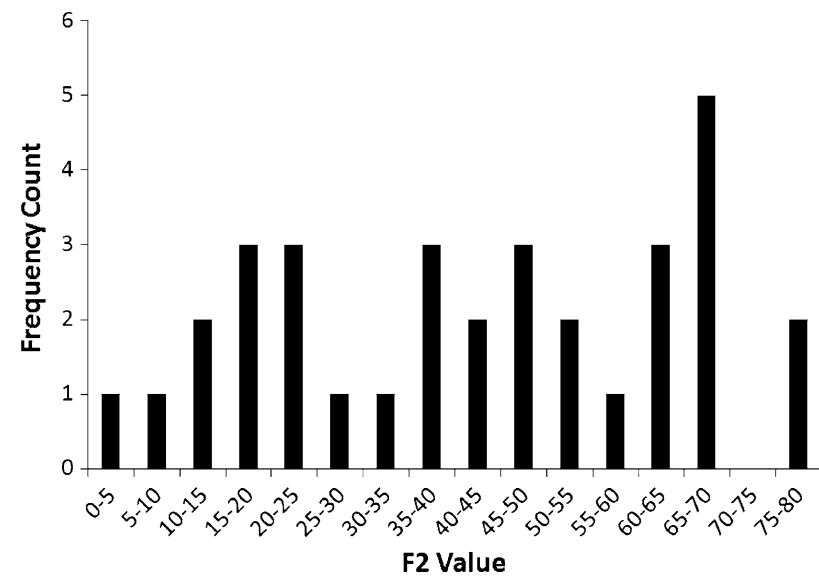

Fig. 4 Histogram showing distribution of F2 parameter

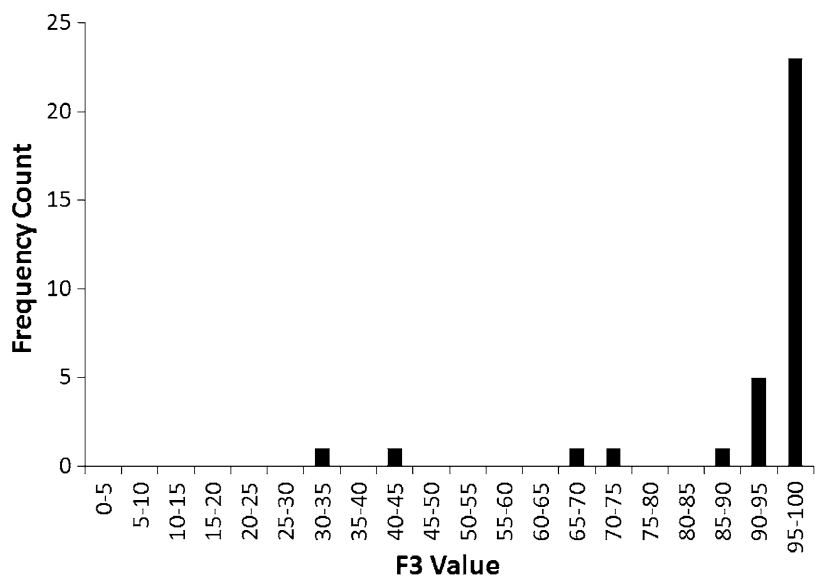

Fig. 5 Histogram showing distribution of F3 parameter

Statistical interpretation

Correlation analysis done (Table 6) between the WQI, DO, $\mathrm{BOD}, \mathrm{TC}, \mathrm{FC}$, free ammonia and $\mathrm{pH}$ revealed that all the parameters negatively impacted the WQI, except DO. BOD is positively correlated to all other parameters considered except for DO and $\mathrm{pH}$. FC and TC are highly negatively correlated with DO. The results highlight a strong correlation among all water quality parameters and WQI.

\section{Discussion}

The study was undertaken to assess the impacts of YAP I and II numerically. In this study, the primary focus was on

Table 6 Correlation between WQI and water quality parameters

\begin{tabular}{lcccccc}
\hline & WQI & BOD & Coliforms, fecal & Coliforms, total & Free ammonia & Oxygen dissolved \\
\hline WQI & 1 & & & & & \\
BOD & -0.79 & 1 & & & & \\
Coliforms, fecal & -0.42 & 0.48 & 1 & 1 & & \\
Coliforms, total & -0.43 & 0.47 & 0.93 & 0.74 & 1 & 1 \\
Free ammonia & -0.79 & 0.81 & 0.70 & -0.44 & -0.84 & 0.80 \\
Oxygen dissolved & 0.91 & -0.84 & -0.44 & -0.41 & -0.79 & 1 \\
pH & 0.83 & -0.72 & -0.37 & & & \\
\hline
\end{tabular}

Table 7 Water quality of River Yamuna at Nizamuddin, Delhi, India (1988, 1996 and 2009)

\begin{tabular}{|c|c|c|c|c|c|c|c|c|}
\hline \multicolumn{3}{|c|}{1988} & \multicolumn{3}{|l|}{1996} & \multicolumn{3}{|c|}{2009} \\
\hline DO & BOD & Total coliforms & DO & BOD & Total coliforms & DO & BOD & Total coliforms \\
\hline 1.9 & 18 & $1,600,000$ & 0.30 & 25.00 & 147818 & 0.0 & 23.00 & $22,516,660$ \\
\hline
\end{tabular}

Data obtained from CPCB and CWC 
six water quality parameters $\mathrm{pH}, \mathrm{DO}, \mathrm{BOD}, \mathrm{TC}, \mathrm{FC}$ and free ammonia. The results showed that even after the implementation of pollution abatement schemes under YAP I and II, the River Yamuna is highly polluted and unfit for its designated use as also given in Table 7.

It was observed that for locations ODRB, Nizamuddin and Okhla the water quality falls in the poor range of CCME WQI. It was also noted that $\mathrm{pH}$ was the only parameter meeting the water quality standards throughout the stretch. The presence of free ammonia is also an important parameter influencing the quality of the river and in high concentrations negatively impacts the river quality.

As the river traverses through the NCT, it becomes polluted via point and non-point sources. During its course, the river receives both partially treated and untreated wastewater via wastewater drains. A huge amount of organic waste when added into the river augments the microbial activity of the aquatic system resulting in the escalation of BOD and depletion of DO. D/S Nizamuddin; in addition to wastewater via drains, the river also receives a major load discharged from Hindon cut carrying wastewater from U.P. Throughout the year, the river flows like an open sewer $\mathrm{d} / \mathrm{s}$ Wazirabad barrage and there is no aquatic life in this stretch. The main reasons for the poor river quality are addition of huge quantity of wastewater generated from the city and no fresh water flow in the river, as also studied by few water quality modeling studies (Paliwal et al. 2007; Sharma and Singh 2009). Only 67\% of the total sewage treatment capacity is being utilized in the capital city. As on March 2008, the sewage treatment capacity of 512.4 MGD (2,321 MLD) existed, but treatment was possible for only 348.04 MGD (1,546 MLD) (State of Environment Report for Delhi 2010). The water quality is highly deteriorated due to lack of minimum perennial fresh water flow in the river along the $22-\mathrm{km}$ stretch between Wazirabad and Okhla. A total of 18 wastewater drains enter the River Yamuna in the NCT stretch. Another reason for the failure of YAP I and II is the role of different monitoring agencies. The data measured by these agencies differ spatially and temporally in terms of number and type of variables being monitored. In view of this, the pollution control strategies developed so far have been found to be inappropriate in meeting the required river quality standards.

\section{Recommendations}

The water quality of the Yamuna River has been continuously degraded all along its NCT stretch. The following section detail out a few strategies to restore the river's water quality. These strategies include both reduction in pollutants and augmentation of the river's assimilative capacity as described below:

Improving the sewerage system

The entire capital city must be sewered and all the wastewater even in low-lying areas near the river should be sent (through pumps if necessary) for treatment and disposal insuring 'zero' discharge in the river. It can be done by upgrading the existing STPs, which do not meet the required disposal standards. The excess sewage entering directly into the river must be tapped and treated. This can be achieved by establishing alternative drainage systems like canals or bandha (a kind of retaining wall or dam extending from a few meters below the riverbed to the river's flood level) on either or both sides of the river, to dispose off the entire wastewater on the river's $d / s$ without lowering the DO levels in the river. Bhargava (1985a, b) highlighted the ways to achieve this designing the outfalls with respect to the flow rates and spacing, keeping in mind the river's self-purifying capabilities. Most importantly, sewage pumping stations must have $24 \mathrm{~h}$ power backup, in view of the frequent power breakdowns. The Delhi government has shifted industries from unplanned areas to planned areas, which dispose wastewater into treatment plants. Eventually, these wastewater streams combine with the ones carrying domestic sewage and finally reach the river. The agricultural practices in NCT must be improved to minimize the effects of chemical fertilizers, insecticides, pesticides, etc.; there is an urgent need of developing public toilets, crematoria and holy ponds near the riverbanks.

The temperature of hot effluents from thermal plants entering the river must be controlled by spray, cascading, etc., as it reduces DO levels by increasing the microbial activity. Riverbanks must be developed as parks with fountains, artificial falls, playground, grassy land, water sports, flow channels, ponds, plantation, etc., which could be used to create artificial aeration facilities to improve the DO level and self-purification of the river (Bhargava 1998). In addition, afforestation along the riverbanks would help in controlling siltation, erosion, agricultural runoffs containing pesticides and fertilizers, etc. In Delhi, another way to minimize the wastewater entering the river can be the establishment of a canal parallel to the river, which carries the wastewater to the treatment plant $\mathrm{d} / \mathrm{s}$.

Augmentation of assimilative capacity

This can be achieved by flow augmentation via impounding the river to use the water stored during the monsoon period and released during the dry periods. Artificial aeration must be done for the stream, its tributaries and the various open drains carrying the wastewater using diffused 
aerators placed at the bottom of the stream, mechanical surface aerators and creating in-stream cascades. DO levels can also be maintained by designing the location of the various outfalls in the river as also described by Bhargava (1983b) and Bhargava et al. (1995).

The results from the WQI study evaluate the critical parameters at various locations in the stretch and will help environmental planners to design, formulate and implement the pollution abatement strategies. Therefore, to design any further pollution abatement interventions under YAP, it is important to perform water quality modeling. The modeling will help the planners to evaluate the proposed interventions prior to their implementation. The environmental auditors and planners must insure that the sewage treatment plants run to their full capacity. According to a World Bank report, by 2021, the estimated wastewater generated by NCT would be 3760 MLD (Economic Survey of Delhi 2008-09). The recycle and reuse of treated wastewater is also one of the main opportunities by which water can be used for irrigation, horticulture and industrial purposes. It can also be supplied for cooling the towers in power stations. Other beneficiary options could be groundwater recharge and the treatment and reuse of sullage water, i.e., water that does not contain human excreta, for flushing toilets, etc. Moreover, it is important to tackle the pollution arising due to non-point sources of pollution such as from the agricultural fields, direct human and animal bathing in the river, immersion of idols, etc.

Therefore, it can be summarized that the control of point sources as well as non-point sources of pollution are vital to clean the river. The river can be cleaned by adopting the management options based on the results obtained from WQI. River quality modeling must be done for the comprehensive assessment of total maximum daily load (TMDL) of pesticides and fertilizers and scenario building studies. Simultaneously, the flow in the river must be augmented. The diffuse pollution via urban and agricultural runoff can be minimized by establishing rainwater harvesting units within the city and sustainable urban drainage systems (SuDs). This will not only curtail the runoff and pollutant loadings, but will also recharge the groundwater. The agriculture runoff which directly enters the river can be reduced by constructing filter and buffer strips around agricultural fields adjacent to the riverbank.

Acknowledgments We sincerely acknowledge the Central Pollution Control Board and the Central Water Commission, India, for providing valuable data regarding the water quality of River Yamuna for the Delhi stretch.

Open Access This article is distributed under the terms of the Creative Commons Attribution License which permits any use, distribution and reproduction in any medium, provided the original author(s) and source are credited.

\section{References}

Bhargava DS (1983a) A light- penetration model for the rivers Ganga and Yamuna. Int J Dev Technol (England) 1(3):199-205

Bhargava DS (1983b) Most rapid BOD assimilation in Ganga and Yamuna rivers. J Environ Eng, Am Soc Civ Eng 109(1):174-188

Bhargava DS (1983c) Use of water quality index for river classification and zoning of Ganga River. Environ Pollut Ser B (England) 6(1):51-67

Bhargava DS (1985a) Technology of rationally setting effluent standards for water pollution administration. J Environ Eng Div Inst Eng (India) 66(1):12-15

Bhargava DS (1985b) Water quality variations and control technology of Yamuna River. Environ Pollut Ser A (England) 37(4):355-376

Bhargava DS (1994) River BOD prediction under non-point discharge conditions. Indian J Eng Mater Sci 1(1):35-40

Bhargava DS (1998) Foolproof pollution control of Indian rivers. Indian J Eng Mater Sci 5(4):162-166

Bhargava DS, Tyagi B, Gakkhar S, (1995) Polynomialization of the models for dissolved oxygen sag parameters, TN: Water Maritime and Energy. In: Proceedings of the Institution of Civil Engineers, UK, 112, 72-74

Bordalo AA, Nilsumranchit W, Chalermwat K (2001) Water quality and uses of the Bangpakong River (Eastern Thailand). Water Res 35(15):3635-3642

Brown RM, McClelland NI, Deininger RA, Tozer RG (1970) A water quality index: do we dare? Water Sewage Works 117:339-343

Canadian Council of Ministers of the Environment (CCME) (2001) Canadian water quality guidelines for the protection of aquatic life: CCME Water Quality Index 1.0, Technical Report. In: Canadian environmental quality guidelines, 1999. Winnipeg: Canadian Council of Ministers of the Environment. http://www. ccme.ca/assets/pdf/wqi_techrprtfctsht_e.pdf

Cash KJ, Saffran KA, Wright CR (2001) Application of Canadian Water Quality Index (CWQI) to PPWB monitoring program. Technical Report, CCME, March 2001

Chapman D (1992) Water quality assessment. Chapman and Hall (on behalf of UNESCO, WHO and UNEP), London

CPCB (2000) Water quality status of Yamuna River, Central Pollution Control Board, New Delhi, series ADSORBS/32/ 1999-2000. April 2000

CPCB (2001-02(a)) Water quality status and statistics. Monitoring of Indian national aquatic resources series (MINARS). MINARS/ 14. Central Pollution Control Board, Delhi, India

CPCB (2002) Water quality criteria and goals. Central Pollution Control Board, New Delhi, series MINARS/7/2001-2002

CPCB (2006-07) Water quality status of River Yamuna (1999-2005), Assessment and development study of river basin series (ADSORBS). ADSORBS/41. Central Pollution Control Board, Delhi, India

Cude CG (2001) Oregon Water Quality Index: a tool for evaluating water quality management effectiveness. J Am Water Resour Assoc 37(1):125-137

Debels P, Figueroa R, Urrutla R, Barra R, Niell X (2005) Evaluation of water quality in the Chillan river (central Chile) using physicochemical parameters and modified water quality index. Environ Monit Assess 110:301-322 
Dunn GW (1995) Trends in water quality variables at the Alberta/ Saskatchewan Boundary. Prepared For The Committee On Water Quality

Economic Survey of Delhi (2008-09), Delhi Planning, India http://delhiplanning.nic.in Accessed on 6th Feb 2011

H'ebert S (1996) D'evelopmentd'un indice de la qualit'ebact'eriologique et physico-chimique de l'eau pour des rivi'eres du Qu'ebec', Report of the Ministi 'ere de 1. Environnement et de la Faune, Qu'ebec, QC, Canada

Horton RK (1965) An index-number system for rating water quality. J Water Pollut Control Fed 37(3):300-306

HT (2004) Pollution in Yamuna river cause of alarm, Hindustan Times, New Delhi 14-11-2004

Husain T (2001) Canadian water quality index determination for three EMAN sites. Ecological Monitoring and Assessment Network, EC, 867 Lakeshore Road, Burlington, ON, Canada, L7R 4A6

Kannel PR, Lee S, Lee YS, Kanel SR, Khan SP (2007) Application of water quality indices and dissolved oxygen as indicators for river water classification and urban impact assessment. Environ Monit Assess 132:93-110

Khan F, Husain T, Lumb A (2003) Water quality evaluation and trend analysis in selected watersheds of the Atlantic region of Canada. Environ Monit Assess 88:221-242

Landwehr JM (1974) Water Quality Indices Construction and Analysis. Dissertation, University of Michigan, Ann Arbor, Michigan, USA

Lumb A, Halliwell D, Sharma T (2002) (October), Canadian Water Quality Index (CWQI) to Monitor the Changes in Water Quality in the Mackenzie River-Great Bear. In: Proceedings of the 29th Annual Aquatic Toxicity Workshop, Whistler, BC, Canada

Lumb A, Halliwell D, Sharma T (2006) Application of CCME Water Quality Index to monitor water quality: a case of the Mackenzie River Basin Canada. Environ Monit Assess 113:411-429

Murphy S (2007) General Information on Dissolved Oxygen. City of Boulder/USGS Water Quality Monitoring. Last Page UpdateMonday April 23, 2007. Retrieved July 10, 2007, from http:// bcn.boulder.co.us/basin/data/BACT/info/DO.html

Ongley E (1998) Modernization of water quality programs in developing countries: issues of relevancy and cost efficiency. Water Quality International, Sep/Oct, 37-42

Ongley ED, Booty WG (1999) Pollution remediation planning in developing countries: Conventional modeling versus knowledgebased prediction. Water Int 24:31-38

Ott W (1978) Environmental indices: theory and practice. Ann Arbor Science, Ann Arbour, Michigan, USA

Paliwal R, Sharma P, Kansal A (2007) Water quality modelling of the river Yamuna (India) using QUAL2E-UNCAS. J Environ Manag 83(2):131-144

Paterson R, Khan AA, Khan H (2003) (September-October) In: Proceedings of the 30th Annual Aquatic Toxicity Workshop, Ottawa, ON, Canada

Pesce SF, Wunderlin DA (2000) Use of water quality indices to verify the impact of Cordoba city (Argentina) on Suquýa River. Water Res 34(11):2915-2926
Rauch W, Henze M, Koncsos L, Reichert P, Shanahan P, Somlyody L (1998) River water quality modelling-I state of the art. Water Sci Technol 38:237-244

River Action Plan, National River Conservation, Directorate working for clean rivers. Ministry of Environment and Forests, India. http://envfor.nic.in/nrcd/NRCD/YAP.htm, Accessed on 4th Feb 2011

Rocchini R, Swain LG (1995) The British Columbia water quality index. Water Quality Branch, EP Department, B.C., Ministry of Environment, Land and Park, Victoria

Rudolf A, Ahumada R, Pe'rez C (2002) Dissolved oxygen content as an index of water quality in San Vicente Bay, Chile (36 degrees, 450S). Environ Monit Assess 78:89-100

SAFE (1995) Strategic assessment of Florida's environment, Florida stream water quality index, statewide summary. online: http://www.pepps.fsu.edu/safe/environ/swq1.html

Said A, Stevens DK, Sehlke G (2004) An innovative index for evaluating water quality in streams. Environ Manage 34(3):406-414

Sanchez E, Colmenarejo MF, Vicente J, Rubio A, Garcia MG, Travieso L (2006) Use of the water quality index and dissolved oxygen deficit as simple indicators of watersheds pollution. Ecological Indicators. doi:10.1016/j.ecolind.2006.02.005

Shanahan P, Henze M, Koncsos L, Rauch W, Reichert P, Somlyody L (1998) River water quality modelling-II Problems of the art. Water Sci Technol 38:245-252

Sharma TC (2002) Canadian Water Quality Index determination for four sites in the Mackenzie River Basin. Ecological Monitoring and Assessment Network, Burlington, ON, Canada, p 58

Sharma D, Singh RK (2009) DO-BOD modeling of River Yamuna for national capital territory, India using STREAM II, a 2D water quality model. Environ Monit Assess 159(1-4):231-240

Somlyody L, Henze M, Koncsos L, Rauch W, Reichert P, Shanaham P (1998) River water quality modelling-III Future of the art. Water Sci Technol 38:253-260

Stambuk-Giljanovic N (1999) Water quality evaluation by index in Dalmatia. Water Res 33(16):3423-3440

State of Environment Report for Delhi (2010) Department of Environment and Forests, Government of NCT of Delhi Level 6, C Wing Delhi Secretariat I P Estate, New Delhi 110002

Steinhart C, Schierow I, Chesters G (1981) A review of water quality and related indices. Great Lakes environmental planning study contribution no. 38, Water Resources Center, University of Wisconsin, Madison, Wisconsin, USA

Steinhart CE, Schierow LJ, Sonzogni WC (1982) Environmental quality index for the Great Lakes. Water Resour Bull 18(6): $1025-1031$

Upadhyay R, Dasgupta N, Hasan A, Upadhyay SK (2010) Managing water quality of River Yamuna in NCR Delhi. Phys Chem Earth Parts A/B/C 36(9-11):372-378

Zandbergen PA, Hall KJ (1998) Analysis of the British Columbia Water Quality Index for watershed managers: a case study of two small watersheds. Water Qual Res J Can 33:519-549 